International Journal of Instruction

e-ISSN: 1308-1470 • www.e-iji.net
July $2019 \bullet$ Vol.12, No.3

p-ISSN: 1694-609X

pp. 439-458

Received: 07/09/2018

Revision: 09/04/2019

Accepted: 14/04/2019

OnlineFirst:10/05/2019

\title{
Compensation, Transparency, and Motivation Effects on the Performance of Junior High School Teachers in Western Seram, Indonesia
}

\section{Josef Papilaya}

Faculty of Teachers Training and Educational Sciences. Universitas Pattimura, Indonesia,josef_papilaya@yahoo.co.id

Paulus Tuakora

SMA Negeri 1 Seram Utara Barat, Indonesia, paulus.tuakora@gmail.com

\section{Muhammad Rijal}

State Institute for Islamic Studies Ambon. IAIN Ambon, Indonesia, rijal_rijal82@yahoo.co.id

This article reports on the effects of motivation, management transparency, and compensation on junior high schools teachers' performance. The current study employed a quantitative design involving 66 teachers serving at 6 public junior high schools in Western Seram regency. Data was collected using a reliable and valid questionnaire. Path analysis was performed to examine the direct or indirect effects of the exogenous variables on the endogenous variables. Findings indicated that compensation did not show any direct effect on teachers' performance, but through transparency (23\%) and motivation (15\%). Meanwhile, transparency was reported to impact teachers' performance directly $(35 \%)$ and had no direct effect on motivation (23\%). The results also suggested an undeviating effect of motivation on teachers' performance $(47 \%)$. Therefore, the total effects of compensation, transparency, and motivation on teachers' performance were $49 \%$, $58 \%$, and $47 \%$ respectively.

Keywords: motivation, transparency, compensation, teachers' performance, management, western Seram

\section{INTRODUCTION}

Organizations need leaders and leadership. Leaders are individuals who, due to their talents and competences, have successfully gained trust from organization members to lead them. Leadership, on the other hand, is a process to motivate, empower, and influence organization members to contribute their effective potentials to achieve

Citation: Papilaya, J., Tuakora, P., \& Rijal, M. (2019). Compensation, Transparency, and Motivation Effects on the Performance of Junior High School Teachers in Western Seram, Indonesia. International Journal of Instruction, 12(3), 439-458. https://doi.org/10.29333/iji.2019.12327a 
organization goals. (Abednia \& Izadinia, 2013; Rahabav, 2014). Effective leadership, according to Siagian (Rahabav, 2014) is able to grow, nurture, and develop cooperative efforts and climate in an organizational life. It is reflected in the ability of a leader to make a decision. Rahabav identifies 6 functions of leadership: 1) to determine the direction, 2) to coordinate, 3) to facilitate, 4) to motivate and animate, 5) to build a network, and 6) to supervise and control (Abednia, 2012; Alam \& Farid, 2011; Alford \& Kettle, 2017).

Schools as an organization constitute a system which involves a large number of components such as students, teachers, administration staff, stakeholders, laboratories, and facilities. Therefore, schools need principals to encourage the optimal functions of the components so that schools' goals can be achieved. As a leader of an educational institution, a principal plays a strategic role in school's management (Buczynski \& Hansen, 2010). According to Ismail, Don, Husin \& Khalid (2018); Ko (2013); Rahabav (2014), there are seven common principal roles. A principal is an educator, a manager, an administrator, a supervisor, a leader, an innovator, and also a motivator. These seven roles are related to each other and should be practiced simultaneously by the principal at school. As schools have an authority to make decisions at a certain level, they are also given a responsibility to be accountable. In line with the school's autonomy policy, there is financial management decentralization in Indonesia. Schools in Indonesia have been flooded by projects, such as DAK (Special funds of accreditation), DAU (Accreditation public funds), BOS (School operational assistance) and many others. Therefore, all related parties expect that schools are able to improve their management which may also result in their enhanced performance. However, many schools in fact are not aware of the financial management substance. This ignorance, needless to say, has affected the schools' motivation and performance.

Performance is achievements shown by employees at work in either completing tasks or doing their duty based on particular standards applied by the holders. Teacher's performance, more specifically, refers to achievements shown by a teacher in doing his/her tasks. Performance is influenced by a number of factors (Cooley \& Shen, 2010; Rahabav, 2014) mentions that an individual's abilities and efforts are the determinants of someone's performance. It is also explained that those efforts are strengthened by motives which are sprung from the individual him/herself. Rahabav (2014) adds that work performance is actually a result of an interaction between motivation and ability. Thus, someone who possesses low ability, despite high motivation s/he has got, cannot have an excellent performance. On the other hand, someone with high ability but low motivation will end up showing a poor performance. Hence, high ability teachers need to be motivated and low ability teachers need to be trained in order to improve their competence and as a result their performance (Eileen Lai Horng, Daniel Klasik \& Susanna Loeb, 2010; Cooley \& Shen, 2010).

Motivation is a state of being encouraged to do certain activities to fulfil some requirements (Handoko, 2005; Kakar \& Pathan, 2017; Mashhadi Heidar, Pahlavan, \& Kavian, 2017). Motivation has the power in determining employees' attitudes at work. It exists to push the employees to finish their tasks so that organizational effectiveness can 
be attained. A highly motivated employee will be able to do his/her job effectively and efficiently and thus has a good performance. Another factor that can also affect teachers' performance is compensation which is strongly associated with funding. Theories mention the importance of compensation in any field of life, especially in education. As educational institutions are often perceived as the producers of educational services that generate skills, knowledge, characters, and values manifested in their graduates, compensation becomes much more essential, particularly to support teachers' professionalism (Mashhadi Heidar, Pahlavan \& Kavian, 2017; Fancera \& Bliss, 2011).

Education decentralization policy demands teachers' professionalism. It requires teachers to possess high creativity to create innovation and reformation in education. Education reformation needs to begin with an improvement in learning process in the classroom. Since teachers are the key factor to determine the success of learning, they deserve adequate compensation (Hendriks \& Steen, 2012; Huber \& Muijs, 2010). Transparency can also bring an impact to teacher's performance. Transparency in management refers to the openness in organizing an activity. In an educational institution, transparent financial management could be referred to the openness of financial resources and amount as well as the details of the expense. Transparency is necessary in order to win trust from parents, society members, and government who constantly support schools' programs. Promoting transparency among the associated parties can be done through the provision of sufficient and accurate information as well as the easiness to access the information (Geldenhuys \& Oosthuizen, 2015).

Issues related to teacher's performance andmotivation, management of school's transparency and compensation are always experienced by schools in general and remote schools in particular which are located far away from the cities. Schools in Western Seram, for example, are lacking in assistance in supervising their teachers, employees, even principals from the local department of education.

\section{LITERATURE REVIEW}

\section{Performance}

Kempa (2015); Moolenaar, Sleegers \& Daly (2012), define performance as the ability to achieve a predetermined goal. Performance refers to the result of someone's work process. According to Rahabav (2014), performance is an individual's or organization's actual achievement through high competence and motivation which are manifested in targeted outputs and outcomes. Notanubun (2015) also adds that performance in general can be understood as the employees' contribution to the advancement of the institution where they work. Performance is the whole integrated elements and processes in an organization. Performance contains individuals' distinctive qualities, employees' attitudes and organizational goals. As is stated by Notanubun (2015), performance in governmental management is the main responsibility of a leader who is supposed to help his/her subordinates to achieve better.

According to Supardi (2014); Rosnarizah (2015); Hoy \& Tarter, (2011), issues on performance in the field of education can be identified from some points of view: 1) Work achievement of an educator is to hold an educational program that can produce 
qualified graduates or output; 2) An educator should be able to provide satisfying services for the community members and students; 3) Education fee should be affordable by all society members; 4) Principals, teachers, and educators should be able to follow social dynamics and therefore improve their abilities to cope with the changes. Smith as cited in Kempa, 2015) defines performance as an activity that is related to three main aspects, organizational behaviors, results, and effectiveness. Performance is not restricted to competence, but also includes motivation or commitment. In other words, performance is the realization of competence and motivation to finish a task, to develop, and to cultivate the environment. Therefore, an individual's or an organization's performance can be evaluated through how they carry out their responsibilities or routines. Regarding teachers whose responsibility to execute learning at school, performance is assessed through the success of learning and the achievement of the students. Teachers' performance, thus, is reflected in their roles and functions inside or outside the classroom as an educator, instructor, and trainer. As they play their roles, teachers' performance can be demonstrated by their activities in planning, conducting, and evaluating learning process of which intensity is based on the teachers' morality and professionalism (Sutherland, Howard \& Markauskaite, 2010; Trent, 2010)

Teaching is a profession that is established on some principles: 1) A teacher must have a talent, interest, calling and idealism, 2) A teacher must be committed to improving the quality of education, faith, piety and noble character, 3) A teacher must possess adequate competences relevant to his/her job, 4) Teachers' income is determined by their work performance, 5) A teacher must be given an opportunity to develop their professionalism, 6) There must be a law to protect teachers' profession, 7) There must be a professional organization that has rights to organize teachers' professional roles (The Indonesian Government Regulation No. 14, 2005). Furthermore, to realize national educational goals "it is compulsory for teachers to have academic qualifications, competence, certificate of educators, and perfect physical and mental health". Teachers are responsible for improving students' achievement. Therefore, teacher's performance can be defined as a state which describes the ability of a teacher to do his/her task at school and to perform learning activities (Supardi, 2013; Wu \& Lee, 2017).

Teacher's performance is also depicted in teacher's attitudes at work. These attitudes may include honesty, work ethics, loyalty, dedication, and participation. In addition, teacher's performance can also be shown by teacher's competences. These competences include teacher's personalities, teacher's pedagogical, social, and professional skills. Evaluating teacher's performance is an important part of management which has a function to identify problems in learning and fix the mistakes so that learning objectives can be achieved. The evaluation of teacher's performance is a process to determine the level of teacher's success in teaching based on certain standards ( Gu Saw Lu, 2014; Kempa, 2015). There are 2 dimensions that can be used to evaluate teacher's performance (Klassen \& Chiu, 2010) Number of products generated, 2) The quality of the products or the competitiveness of the products/service generated by the teacher as an educator or an instructor. Students, parents, and stakeholders are the school's main consumers. Therefore, the quality of the educational services will be determined by their reactions. 


\section{Work Motivation}

Motivation drives someone to do something to attain a particular objective. Motivation can also be defined as a plan or a wish to head towards success and avoid failure. A motivated individual is the one who has the strength to achieve success in his/her life. Gobena (2018); Siagian (2004); Melekoglu \& Wilkerson (2013), state that motivation encourages an organization member to exert all his/her abilities, skills, energy, and time to perform actions in order to reach organizational targets.

Gobena (2018); Siagian (2004); Melekoglu \& Wilkerson (2013), motivation can be explained in these three things: First: the provision of motivation has a direct connection with the efforts of a member of an organization to attain organizational objectives which also contain his/her personal interests. Second: motivation is an interrelated process between efforts and fulfillment of a particular need. In other words, motivation represents an individual's willingness to work hard to achieve an organizational target. This desire, nevertheless, highly depends on that particular individual's ability to satisfy his/her needs. Third: a need is an internal state which motivates someone to make an attempt meaningful which means that the unfulfillment of the need will result in a tension; therefore, the higher the tension, the harder the effort. From the explanations, it is clear that motivation can be driven either from inside (internal motivation) or outside (external motivation). Both intrinsic and extrinsic factors of motivation can be positive or negative. The key to becoming successful in motivating the employees is to understand these factors (Molavi, Biria \& Chalak, 2018; Ofojebe, 2010; Papi \& Abdollahzadeh, 2012).

Meanwhile, Handoko (2001) argues that motivation is a result of a set of internal or external processes which leads to an individual's enthusiasm to do an activity. Intrinsic motivation makes someone feel satisfied doing a certain activity while extrinsic motivation comes from elements outside the job that makes someone feel encouraged. Status or compensation can be an exemplary form of the extrinsic motivation. In conclusion, motivation can come from inside or outside an individual. Similarly, teacher's motivation can be sourced from inside the teacher him/herself or from outside, such as from the institution.

Problems in this research: 1 whether there is a direct impact significant of compensation of the performance of teachers; 2 ) is there a direct impact significant from transparency of the performance of teachers 3 ) is there a direct impact significant of motivation of the performance of teachers; 4 whether is the indirect significantly from compensation of the performance of teachers through the provision of motivation; 5 ) is there indirect effect significant from transparency of the performance of teachers through the provision of motivation; 6 whether is the indirect significantly from compensation of the performance of teachers through transparency; and 7 whether is the indirect significantly from compensation of the performance of teachers through transparency and motivation.

\section{METHOD}

The kind of this research is the correlation which aims to review the influence of compensation, transparency, and motivation effects on the performance of junior high school teachers in western spooky, Indonesia 


\section{Readability and Validity of the Instrument}

The readability test was conducted to the questionnaire (compensation, transparency, and motivation) to examine unfamiliar words or words that were difficult to understand by the respondents. Two experts were invited to perform a thorough examination on the questionnaire, Dr. A. Sahalessy and Dr. Th. R. Souisa. Researchers used two validator expert on the grounds that they expert in breeding development instrument to motivate and expert in psychology tests.

\section{Revision 1}

After conducting the readability and validity tests (content and construct validity), the instrument was revised accordingly.

\section{Instrument Tryout}

The next stage was to tryout the instrument to fourty teachers from two schools selected outside the research population and samples, namely SMP Negeri 2 Taniwel and SMP Persiapan Negeri 2 Taniwel.

\section{Validity Test}

A valid instrument can measure properly. It, therefore, can provide an appropriate result relevant to what should be tested in the first place. In other words, the instrument can elicit accurate facts from the circumstances being measured. The use of an invalid instrument will lead to misinterpretation of the data. The validity of the instrument used in the current study was measured using the Correlation Product Moment. The results of the validity test of the instrument are presented in the following table.

Table 1

The Results of the Validity Test of the Research Instrument

\begin{tabular}{llll}
\hline \multicolumn{1}{c}{ Variable } & \multicolumn{2}{l}{ Number of items } & \\
\cline { 2 - 4 } & Tested & Invalid & Valid \\
\hline Teacher's Performance & 58 & 28 & 30 \\
\hline Teacher's Motivation & 30 & 10 & 20 \\
\hline Transparency Management & 24 & 2 & 22 \\
\hline Compensation Management & 27 & 8 & 19 \\
\hline Total & 139 & 48 & 91 \\
\hline
\end{tabular}

\section{Reliability Test}

A reliability test was conducted to prove that an instrument can be trusted to collect data. The reliability of the research instrument was measured using the Kuder and Richardson. The results of the reliability test of the research instrument are recorded in Table2 (the results of the calculation are attached on this document) 
Table 2

The Results of the Reliability Test of the Research Instrument

\begin{tabular}{lllll}
\hline Variables & Reliability & \multicolumn{2}{l}{ Notes } \\
\cline { 2 - 4 } & Number of Items & r calculated & r table & \\
\hline Teacher's Performance & 30 & 0,99746 & 0,361 & High \\
\hline Teacher's Motivation & 20 & 0,86350 & 0,444 & High \\
\hline Transparency Management & 22 & 0,98500 & 0,413 & High \\
\hline Compensation Management & 19 & 0,85946 & 0,456 & High \\
\hline
\end{tabular}

\section{Revision 2}

The instrument was revised based on the results of the tryout. This revised instrument was used to collect data of this research. Total items instrument is 91 consisting of: Teacher's Performance (30 items); Teacher's Motivation (20 items); Transparency Management (22 items); and Compensation Management (19 items)

\section{Data Analysis Technique}

Data analysis was performed using descriptive statistics and inferential statistics analyses. The descriptive statistics analysis was conducted to provide practical information of the data while the inferential statistics analysis was performed to explain the degree of the relationship between the independent and dependent variables. This study specifically employed a regression analysis where a correlation and a cause-effect relationship between variables (path analysis) would be revealed (Sitepu, 1994). Mostly, the analyses were performed manually, using Microsoft Excel and SPSS.

\section{FINDINGS}

\section{Teacher's Performance (Y)}

A 30-item questionnaire was distributed to 66 junior high school (SMP) teachers as the respondents. The results showed a minimum score of 54, a maximum score of 113, an average score of 92.27, median 96.50, total variance 197.80, standard deviation 14.06, and a data range score of 54-59. Table 3 describes the data in details.

Table 3

Statistical Description of Teacher's Performance Data

\begin{tabular}{ll}
\hline \multicolumn{2}{l}{ Teacher's Performance } \\
\hline Mean & 92.27 \\
\hline Median & 96.50 \\
\hline Maximum & 113 \\
\hline Minimum & 54 \\
\hline Std. deviation & 14.06 \\
\hline Variance & 197.80 \\
\hline Range & 59 \\
\hline
\end{tabular}

Teacher's performance was categorized into very high, medium, low, and very low. These data were transcribed in percentages as follows. 
Table 4

The Percentages of Teacher's Performance Scores

\begin{tabular}{lllll}
\hline Value Intervals & Frequency & Percentage $(\%)$ & Grade & Category \\
\hline $108-120$ & 9 & 13.64 & A & Very high \\
\hline $90-107,9$ & 34 & 51.52 & B & High \\
\hline $72-89,9$ & 15 & 22.73 & C & Medium \\
\hline $48-71,9$ & 8 & 12.12 & D & Low \\
\hline$<48$ & 0 & 0.00 & E & Very Low \\
\hline Total & 66 & & & \\
\hline
\end{tabular}

Table 4 showed that $9(13.64 \%)$ teachers were in very high category, $34(51.52 \%)$ teachers were in high category, $15(22.73 \%)$ teachers were in medium category, 8 (12.12 $\%)$ were in low category, but none was in very low category. The results indicated that the average score of teacher's performance (92.27) was in high category (90-107.9).

\section{Compensation Management $\left(\mathbf{X}_{1}\right)$}

The results of the analysis of a 19-item questionnaire on compensation management distributed to the 66 respondents suggested following scores: minimum score of 30 , maximum score of 74 , mean 47 , median 44 , variance 153.44 , standard deviation 12.39 , and data range score of $30-44$. In details, the description of the data can be seen in the table below.

Table 5

Statistical Description of Compensation Management Data

Compensation Management

\begin{tabular}{ll}
\hline Mean & 47.23 \\
\hline Median & 44 \\
\hline Maximum & 74 \\
\hline Minimum & 30 \\
\hline Std. deviation & 12.39 \\
\hline Variance & 153.40 \\
\hline Range & 44 \\
\hline
\end{tabular}

Compensation management was categorized into very high, medium, low, and very low. These data were transcribed in percentages as follows.

Table 6

The Percentages of Compensation Management Scores

\begin{tabular}{lllll}
\hline \multicolumn{1}{c}{ Value Intervals } & Frequency & Percentage $(\%)$ & Grade & Category \\
\hline $68.4-76$ & 4 & 6.06 & A & Very high \\
\hline $57.0-68.3$ & 13 & 19.70 & B & High \\
\hline $45.6-56.9$ & 14 & 21.21 & C & Medium \\
\hline $30.4-45.5$ & 31 & 46.97 & D & Low \\
\hline$<30.4$ & 4 & 6.06 & E & Very Low \\
\hline Total & 66 & & & \\
\hline
\end{tabular}

Table 6 indicated that $6(6.06 \%)$ were in very high category, $13(19.70 \%)$ were in high category, $14(21.21 \%)$ were in medium category, $31(46.97 \%)$ were in low category, 
and $4(6.06 \%)$ were in very low category. The results thus suggested that compensation management at Junior high school in Western Seram was in medium category (46.97).

\section{Transparency Management $\left(\mathbf{X}_{2}\right)$}

The results of the analysis of a 22-item questionnaire on transparency management distributed to the 66 respondents suggested following scores: minimum score of 37, maximum score of 88 , mean 62.83 , median 64 , variance 298.9 , standard deviation 17.29, and data range score of 37-51. In details, the description of the data can be seen in the table below.

Table 7

Statistical Description of Transparency Management Data

\begin{tabular}{ll}
\hline \multicolumn{2}{l}{ Transparency Management } \\
\hline Mean & 62.83 \\
\hline Median & 64 \\
\hline Maximum & 88 \\
\hline Minimum & 37 \\
\hline Std. deviation & 17.29 \\
\hline Variance & 298.91 \\
\hline Range & 51 \\
\hline
\end{tabular}

Transparency management scores were categorized into very high, high, medium, low, and very low. The interpretation of the scores was presented in Table 8 .

Table 8

The Percentages of Transparency Management Scores

\begin{tabular}{lllll}
\hline Value Intervals & Frequency & Percentage $(\%)$ & Grade & Category \\
\hline $79.2-88$ & 13 & 19.70 & A & Very high \\
\hline $66-79.1$ & 19 & 28.79 & B & High \\
\hline $52.8-65.9$ & 7 & 10.61 & C & Medium \\
\hline $35.2-52.7$ & 27 & 40.91 & D & Low \\
\hline$<35.2$ & 0 & 0.00 & E & Very Low \\
\hline Total & 66 & & & \\
\hline
\end{tabular}

Table 8 indicated that $13(19.70 \%)$ teachers were in very high category, $19(28.79 \%)$ were in high category, $7(10.61 \%)$ were in medium category, $27(40.91 \%)$ were in low category, and none was in very low category. The results thus suggested that in average the scores of transparency management at Junior high school (SMP) in Western Seram were in medium category (62.83).

\section{Work Motivation $\left(\mathbf{X}_{3}\right)$}

The results of the analysis of a 20 item questionnaire on work motivation distributed to the 66 respondents suggested following scores: minimum score of 44 , maximum score of 80 , mean 60.56 , median 60 , variance 61.82 , standard deviation 7.86 , and data range score of $36-44$. 
Table 9

Statistical Description of Work Motivation

\begin{tabular}{ll}
\hline \multicolumn{2}{l}{ Work Motivation } \\
\hline Mean & 60,56 \\
\hline Median & 60 \\
\hline Maximum & 80 \\
\hline Minimum & 44 \\
\hline Std. deviation & 61.819 \\
\hline Variance & 298.91 \\
\hline Range & 36 \\
\hline
\end{tabular}

Work motivation scores were categorized into very high, high, medium, low, and very low. The interpretation of the scores was presented in Table 10.

Table 10

The Percentages of Work Motivation Scores

\begin{tabular}{lllll}
\hline Value Intervals & Frequency & Percentage $(\%)$ & Grade & Category \\
\hline $72-80$ & 7 & 10.61 & A & Very high \\
\hline $60-71.9$ & 29 & 43.94 & B & High \\
\hline $48-59.9$ & 14 & 21.21 & C & Medium \\
\hline $32-47.9$ & 14 & 21.21 & D & Low \\
\hline$<32$ & 2 & 3.03 & E & Very Low \\
\hline Total & 66 & & & \\
\hline
\end{tabular}

Table 10 suggested that $7(10.61 \%)$ teachers perceived that work motivation was in very high category, $29(43.94 \%)$ categorized work motivation into high category, 14 $(21.21 \%)$ categorized it into medium category, $14(21.21 \%)$ into low category and 2 $(3.03 \%)$ into very low category. The results thus suggested that in average the scores of work motivation at Junior high school (SMP) in Western Seram were in high category (60.56).

Table 11

The Results of the Calculation of Compensation $\left(\mathrm{X}_{1}\right)$ Indirect Effect on Teacher's Performance (Y) through Motivation $\left(\mathrm{X}_{3}\right)$

\begin{tabular}{lllll}
\hline$($ Direct $)$ Effect & Path Coefficients $\left(\mathrm{P}_{\mathrm{ii}}\right)$ & $\mathrm{p}$-value & Criteria & Interpretation \\
\hline $\mathrm{X}_{1}$ on $\mathrm{X}_{3}\left(\mathrm{P}_{31}\right)$ & 0.232 & 0.035 & $0.035<0.05$ & Significant \\
\hline $\mathrm{X}_{3}$ on $\mathrm{Y}\left(\mathrm{P}_{\mathrm{y} 3}\right)$ & 0.469 & 0.000 & $0.000<0.05$ & Significant \\
\hline & & & & \\
\hline & $\mathrm{P}_{31} \times \mathrm{P}_{\mathrm{y} 3}=0.232 \times 0.469=0,11$ & & \\
\hline
\end{tabular}

The significant path coefficients between compensation $\left(\mathrm{X}_{1}\right)$ and motivation $\left(\mathrm{X}_{3}\right)\left(\mathrm{P}_{31}=\right.$ 0.232 with $\mathrm{p}$-value $=0.035<0.05)$ and between motivation $\left(\mathrm{X}_{3}\right)$ and teacher's performance $(\mathrm{Y})\left(\mathrm{P}_{\mathrm{y} 3}=0.469\right.$ with $\mathrm{p}$-value $\left.=0.000<0.05\right)$ suggested that compensation had a significant indirect effect on teacher's performance $\left(\mathrm{P}_{31}\right.$ dan $\mathrm{Py}_{3}=(0.232) \mathrm{x}$ $(0.469)=0.11)$. 
Table 12

The Results of the Calculation of Compensation $\left(\mathrm{X}_{1}\right)$ on Teacher's Performance (Y) through Transparency $\left(\mathrm{X}_{2}\right)$ and Motivation $\left(\mathrm{X}_{3}\right)$

\begin{tabular}{lllll}
\hline Direct Effect & Path Coefficients $\left(\mathrm{P}_{\mathrm{ii}}\right)$ & $\mathrm{p}$-value & Criteria & Interpretation \\
\hline $\mathrm{X}_{1}$ on $\mathrm{X}_{2}\left(\mathrm{P}_{21}\right)$ & 0.653 & 0.000 & $0.000<0.05$ & Significant \\
\hline $\mathrm{X}_{2}$ on $\mathrm{X}_{3}\left(\mathrm{P}_{32}\right)$ & 0.232 & 0.035 & $0.035<0.05$ & Significant \\
\hline $\mathrm{X}_{3}$ on $\mathrm{Y}\left(\mathrm{P}_{\mathrm{y} 3}\right)$ & 0.469 & 0.000 & $0.000<0.05$ & Significant \\
\hline \multicolumn{3}{c}{$\left.\mathrm{X}_{1} \rightarrow \mathrm{X}_{2} \rightarrow \mathrm{X}_{3} \rightarrow \mathrm{Y}\right)$} & & $\mathrm{P}_{21} \mathrm{X} \mathrm{P}_{32} \mathrm{P}_{\mathrm{y} 3}=0.653 \times 0.232 \times 0.469=0.15$ \\
\hline
\end{tabular}

The significant path coefficients between compensation $\left(\mathrm{X}_{1}\right)$ and transparency $\left(\mathrm{X}_{2}\right)\left(\mathrm{P}_{21}\right.$ $=0.653$ with $\mathrm{p}$-value $=0.000<0.05)$ and between transparency $\left(\mathrm{X}_{2}\right)$ and motivation $\left(\mathrm{X}_{3}\right)\left(\mathrm{P}_{32}=0.232\right.$ with $\mathrm{p}$-value $\left.=0.035<0.05\right)$ as well as path coefficient of $\mathrm{P}_{\mathrm{y} 3}=0.469$ $(\mathrm{p}$-value $=0.000<0.05)$ indicated that compensation had a significant indirect effect on teacher's performance $(\mathrm{Y})$ through transparency $\left(\mathrm{X}_{2}\right)$ and motivation $\left(\mathrm{X}_{3}\right)$ as the intervening variables $\left(\mathrm{P}_{21} . \mathrm{P}_{32} . \mathrm{Py}_{3}=(0.653) \times(0.485) \times(0.469)=0.15\right)$. The result of the summation of the direct and indirect effects of compensation on other variables $(0.23+0.11+0.15=0.49)$ suggested that $49 \%$ teacher's performance might be affected by compensation indirectly through transparency and motivation as the intervening variables.

\section{Transparency $\left(\mathrm{X}_{2}\right)$ Effect on Teacher's Performance (Y)}

Based on the results of the hypotheses testing, the path coefficients could be summarized as follows:

Table 13

The Result of the Calculation of Transparency $\left(\mathrm{X}_{2}\right)$ on Teacher's Performance (Y)

\begin{tabular}{cllll}
\hline Direct Effect & Path Coefficients $\left(\mathrm{P}_{\mathrm{ij}}\right)$ & $\mathrm{p}$-value & Criteria & Interpretation \\
\hline $\mathrm{X}_{2}$ on $\mathrm{Y}\left(\mathrm{P}_{\mathrm{y} 2}\right)$ & 0.350 & 0.001 & $0.002<0.05$ & Significant \\
\hline & $\mathrm{P}_{\mathrm{y} 2}=0.35$ & & & \\
$\left(\mathrm{X}_{2} \rightarrow \mathrm{Y}\right)$ & & & & \\
\hline
\end{tabular}

The significant path coefficients between transparency $\left(\mathrm{X}_{2}\right)$ and teacher's performance (Y) $\left(\mathrm{P}_{\mathrm{y} 2}=0.350\right.$ with $\mathrm{p}$-value $\left.=0.001>0.05\right)$ showed that transparency had a significant direct effect on teacher's performance.

Table 14

The Result of the Calculation of Transparency $\left(\mathrm{X}_{2}\right)$ on Teacher's Performance (Y) through Motivation $\left(\mathrm{X}_{3}\right)$

\begin{tabular}{lllll}
\hline Direct Effect & Path Coefficients $\left(\mathrm{P}_{\mathrm{ij}}\right)$ & $\mathrm{p}$-value & Criteria & Interpretation \\
\hline $\mathrm{X}_{2}$ on $\mathrm{X}_{3}\left(\mathrm{P}_{32}\right)$ & 0.485 & 0.000 & $0.000<0.05$ & Significant \\
\hline $\mathrm{X}_{3}$ on $\mathrm{Y}\left(\mathrm{P}_{\mathrm{y} 3}\right)$ & 0.469 & 0.000 & $0.000<0.05$ & Significant \\
\hline & & $\mathrm{P}_{32} \times \mathrm{P}_{\mathrm{y} 3}=0.23$ & \\
\hline
\end{tabular}


The significant path coefficients between transparency $\left(\mathrm{X}_{2}\right)$ and motivation $\left(\mathrm{X}_{3}\right)\left(\mathrm{P}_{32}=\right.$ 0.485 with $\mathrm{p}$-value $=0.000<0.05)$ and between motivation $\left(\mathrm{X}_{3}\right)$ and teacher's performance $\left(\mathrm{P}_{\mathrm{y} 3}=0.469 \mathrm{p}\right.$-value $\left.=0.000<0.05\right)$ indicated that transparency had an indirect effect $\mathrm{o}$ teacher's performance through motivation $\left(\mathrm{P}_{32}\right.$ and $\mathrm{Py}_{3}=(0.485) \mathrm{x}$ $(0.469)=0.23)$. Based on the calculation of the direct and indirect effects $(0.35+0.23=$ 0.58 ), it can be concluded that $58 \%$ teacher's performance might be influenced by transparency indirectly through motivation as the intervening variable.

\section{The effect of motivation $\left(X_{3}\right)$ on teacher's performance $(Y)$}

Based on the results of the hypotheses testing, the path coefficient could be summarized as follows:

Table 15

The Result of the Calculation of Motivation $\left(\mathrm{X}_{3}\right)$ on Teacher's Performance $(\mathrm{Y})$

\begin{tabular}{lllll}
\hline Direct Effect & Path Coefficients $\left(\mathrm{P}_{\mathrm{ij}}\right)$ & $\mathrm{p}$-value & Criteria & Interpretation \\
\hline $\mathrm{X}_{3}$ on $\mathrm{Y}\left(\mathrm{P}_{\mathrm{y} 3}\right)$ & 0.469 & 0.000 & $0.000<0.05$ & Significant \\
\hline & $\mathrm{P}_{\mathrm{y} 3}=0.469$ & & &
\end{tabular}

$\left(\mathrm{X}_{3} \rightarrow \mathrm{Y}\right)$

The significant path coefficient between motivation $\left(\mathrm{X}_{3}\right)$ and teacher's performance $(\mathrm{Y})$ $\left(\mathrm{P}_{\mathrm{y} 3}=0.469\right.$ with $\mathrm{p}$-value $\left.=0.000>0.05\right)$ indicated that motivation had a significant direct effect on teacher's performance.

\section{DISCUSSION}

\section{The Direct Effect of Compensation $\left(X_{1}\right)$ on Teacher's Performance $(Y)$}

The path coefficient between compensation and teacher's performance ( -0.183 with pvalue $=0.110 / 2=0.055>0.05)$ suggested that compensation including the provision of comfortable working spaces, health facilities, transportation fees, leaves, allowances, rewards or punishment if necessary had no direct effect on teacher's performance. In line with this finding, Simangunsong (2009), showed that compensation had an insignificant and weak correlation with teacher's performance. However, Anoki (2010) found that compensation had a positive significant effect on teacher's performance. Meanwhile, research findings by Aprijon (2014) have proven that compensation and teacher's performance have a strong relationship. Partially (52.1\%), teacher's performance could be affected by compensation. A good performance will give you the results of a good job, and the results of a good job will get high appreciation and that affect the compensation

The results of the current research indicate that $45 \%$ of teacher's performance is influenced by other factors, such as teacher's certification. Teacher's certification is another form of compensation provided by the government for teachers that are considered. The certification as a form of compensation in each teacher different, depending on performance made. If a teachers have a good performance, and the certification, received will be great and vice versa for teachers who have a poor performance will be low. Research by Era Tama (2013) has suggested that certification 
has positive and significant effects on elementary teacher's performance in Ngawi. In fact, $47.8 \%$ of teacher's performance's variables are affected by teacher's certification. Despite the fact that compensation has no direct effect on teacher's perfomance, principals still have to continue to think about improvements in compensating teachers.

\section{The Direct Effect of Transparency $\left(X_{2}\right)$ on Teacher's Performance $(Y)$}

Findings of this study have revealed that transparency has a direct effect on teacher's performance. Therefore, schools need to provide an opportunity for parents, teachers, and students to be well informed about the planning, implementation, and evaluation of a program and a policy as well as to share information with other people. Therefore, it is clear that indicators of transparency may include the principal's commitment to be open about the planning, implementation, and evaluation of a school's program which involves parents, teachers, and the school's committee and to provide facilities that can help disseminate the school's recent policies and decisions. RAKER (regular meetings), RAPBS (budget) planning, socialization of the use of BOS, fair divisions of staff work, the involvement of parents and teacher's council in every decision-making process, a new and open students' admission program are exemplary actions that can reflect the principal's commitment to being transparent. Parents can also be involved in school's financial organization, such as the RAPBS.

The indicators of the availability of facilities to disseminate various school decisions and policies can be seen when schools have financial administration books, principals conduct program evaluation meetings every week, monthly or quarterly, schools have records of complaints, technical input and suggestions from parents and the community. Decisions or policies and RAPS results which are posted on the information board enable various users to access them. The existence of openness in planning, the implementation of various school programs can be seen when every project obtained by the school is known by all teachers and its implementation is open, the management of BOS funds is known by all teachers, the scholarship is administered openly and fairly, data is sent online to students and teachers openly. Indicators of transparency management above can help build parents and community member's trust in schools and teachers' trust in the principal.

According to Surya Darma (2007) the principle of transparency is to create mutual trust between the government and the community through the provision of information and easiness to acquire accurate and adequate information. Therefore, in the context of implementing transparency schools can increase mutual trust between parents and schools, or between teachers and principals so that ultimately not reducing teacher performance can even improve teacher performance. The results of other studies conducted by Aditya Utama (2014) showed the opposite result, namely that there was no effect of transparency on teacher performance partially, but simultaneously transparency together with accountability and financial responsibility had a significant effect on teacher performance. Thus it can be said also that the implementation of good transparency management if accompanied by the implementation of accountability and good financial responsibility, will further improve teacher performance. 
Similarly, Sukanada (2010) concludes that leadership variables have positive and significant direct effects on employee's performance, the better the leadership, the better the employee's performance and vice versa. Thus, it can be noted also that transparent leadership of the principals will directly improve teacher performance.

\section{The Direct Effect of Motivation $\left(X_{3}\right)$ on Teacher's Performance $(Y)$}

Findings of this study suggest that motivation has a direct effect on teacher's performance. Either internal or external motivation such as fulfillment of basic needs, curiosity, the desires to advance in a career, to get awards and to be recognized by others, or the desire to be accepted by the group and to be respected or to get quality results and be involved in various activities, or to have good relationships with superiors and colleagues, and to work in a safe and comfortable place can empower teachers to perform even better.

Likewise, Supardi (2014); Oko (2014); Rastegari \& Narafshan (2017) states that one of the factors that may influence employee's work performance is motivation. According to Siagian (2004) motivation is the driving force that causes a member of an organization to be encouraged to mobilize their abilities in the form of expertise, skills, energy and time to organize various activities in order to achieve the organizational goals and objectives. This means that when a teacher is given motivation in the form of motivation from within and from school, his/her performance will certainly increase. The same thing was also conveyed by Ivancevich (Rahabav, 2014) that someone who has abilities with effort will perform better. Efforts are affected by the strength of the motives (motivation) that exist in the individual and also the environment factors that contribute to one's performance. Motivation is a make someone to perform an act .Motivation high influences the performance and that resulted in the outcome

\section{The Indirect Effect of Compensation $\left(X_{I}\right)$ on Teacher's Performance $(Y)$ through Motivation $\left(\mathrm{X}_{3}\right)$}

The results of the present research indicate that compensation contributes $11 \%$ to teacher's performance through motivation. According to Mathis and Jackson (2000), one of the possible ways to motivate employees is through compensation. Similarly, Haryono (Herdian Dito, 2010) states that compensation has a positive effect on performance, but through motivation as the intervening variable.

A sense of satisfaction with the compensation provided by the school in the form of salaries, bonus benefits and various adequate facilities will foster teacher's motivation because the teacher feels valued and supported at work. High motivation makes teachers become more focused and attentive to efforts to achieve good work as what the school expects from them. As a result, their performance is enhanced and so is the quality of the education.

The Indirect Effect of Transparency $\left(\mathrm{X}_{2}\right)$ on Teacher's Performance (Y) through Motivation $\left(\mathrm{X}_{3}\right)$

Findings of the current study suggest that transparency contributes $23 \%$ to teacher's performance through motivation. The practice of transparency is intended to build trust 
and confidence in the school that the school is clean and free from corruption practices. Transparency aims to create mutual trust between schools and the society through the provision of access to adequate and accurate.

Therefore, to create an effective relationship between school and society, the reliability of a principal must be evaluated regularly. Since the community will keep paying attention to what happens to students in school and what parents think about school, especially the thoughts and judgments of teachers on the headmaster's leadership, a principal is required to always strive to foster and enhance good cooperation between schools and the community through transparent management. Transparent management can be realized in the implementation of various school programs, decision making, and financial arrangements. When teachers trust the headmaster, they will feel more encourage to improve their performance.

\section{The Indirect Effect of Compensation ( $\left.X_{I}\right)$ on Teacher's Performance (Y) through Transparency $\left(\mathrm{X}_{2}\right)$}

Findings of this study show that compensation contributes $23 \%$ to teacher's performance indirectly through transparency. If compensation is increased, teachers automatically will trust the principal and as a result they become more encouraged to perform better at work.

The provision of comfortable work space, health facilities, leave, transportation fees, incentives, benefits, awards and punishment if necessary cannot affect teacher's performance directly. However, through management transparency, when teachers are given adequate compensation, they start to develop trust in the principal. Thus, the working atmosphere becomes much better and much more open. This sort of good environment will ultimately have an impact on teacher's performance. Therefore, compensation must remain the main concern of school leaders because it is one of the factors that can influence teacher's performance (Miri, Alibakhshi \& Mostafaei Alaei, 2017).

The Indirect Effect of Compensation $\left(X_{I}\right)$ on Teacher's Performance $(Y)$ through Transparency $\left(\mathrm{X}_{2}\right)$ and Motivation $\left(\mathrm{X}_{3}\right)$.

The results of the current study suggest that compensation can indirectly improve teacher's performance 15\% through transparency and work motivation. Proper and fair compensation will result in creating a pleasant working atmosphere so that every activity can be performed in a good, transparent, accountable way. Improving the employees' motivation, needless to say, will trigger the betterment of the employees' performance. This finding is in line with Saydam's (Riana, 1996; Li \& Zhou, 2017)) opinion which states that giving equal compensation not only can affect the material conditions of employees but also can encourage the employees to be more diligent and more initiative. In other words, adequate compensation increases the employees' satisfaction so that they feel more motivated to improve their skills and abilities that are needed to do the job. 


\section{CONCLUSIONS}

1. Compensation has an indirect effect on teacher's performance through motivation. This result indicates that compensation increases teacher's motivation. When teachers feel more motivated, they will perform better at work.

2. Compensation has an indirect effect on teacher's performance through transparency. This finding shows that compensation helps create a more transparent management so that teachers trust the principal and as a result work better at school.

3. Compensation has an indirect effect on teacher's performance through transparency and motivation. Compensation helps increase transparency and motivation. As a result, teacher' performance is improved accordingly.

4. Transparency has a direct effect on teacher's performance. A transparent school environment will help improve teacher's performance.

5. Transparency has an indirect effect on teacher's performance through motivation. Teachers feel motivated when the working atmosphere is transparent. Well motivated teachers are able to perform better than those who are not.

6. Motivation has a direct effect on teacher's performance. This result indicates that an immediate improvement in teacher's performance can be expected once there is an increase in motivation.

7. The total effect of compensation on teacher's performance is $49 \%$ which means that compensation contributes to the $49 \%$ increase of teacher's performance.

The total effect of transparency on teacher's performance is $58 \%$, which means that teacher's performance will increase 58\% when transparency is improved.

\section{REFERENCES}

Abednia, A. (2012). Teachers' professional identity: Contributions of a critical EFL teacher education course in Iran. Teaching and Teacher Education, 28(5), 706-717.

Abednia, A., \& Izadinia, M. (2013). Critical pedagogy in ELT classroom: Exploring contributions of critical literacy to learners' critical consciousness. Language Awareness, 22(4), 338-352.

Alam, T. A., \& Farid, S. (2011). Factors affecting teachers motivation: International Journal of Business and Social Science, 2(1).

Alford, J., \& Kettle, M. (2017). Teachers' reinterpretations of critical literacy policy: Prioritizing praxis. Critical Inquiry in Language Studies, 14(2-3), 182-209.

Aprijon. (2014). The influence of compensation of the performance of teachers senior high school in Bangkinang, indonesia. Thesis. (In Indonesia: Pengaruh Kompensasi Terhadap Kinerja guru SLTA Di ecamatan Bangkinang. Hasil Tesis)

Buczynski, S., \& Hansen, C. B. (2010). Impact of professional development on teacher practice: Uncovering connections. Teaching and Teacher Education, 26, 599-607. 
Cooley, V. E., \& Shen, J. (2010). School accountability and professional job responsibilities: A perspective from secondary principals. NASSP Bulletin, 87(634), 1025.

Darma, Surya. (2007). Financial management institutions, the directorate of teaching staff, general directorate increasing the quality of teachers and education staff, the ministry of national education. (In Indonesia: Manajemen Keuangan insitusi, Direktorat Tenaga Kependidikan, Direktorat Jendral Peningkatan Mutu Pendidik dan Tenaga Kependidikan, Departemen Pendidikan Nasional).

Era Tama Syai Moqsa Prasetyo Isbandono (2013). The influence of certification allowances on the performance of primary school teachers in ngawi, Indonesia. A thesis. (In Indonesia: Pengaruh Tunjangan Sertifikasi Terhadap Kinerja Guru Sekolah Dasar Negeri Di Kecamatan Pangkur Kabupaten Ngawi. Hasil skripsi)

Fancera, S. F., \& Bliss, J. R. (2011). Instructional leadership influence on collective teacher efficacy to improve school achievement. Leadership and Policy in Schools, 10(3), 349-370.

Geldenhuys, J. L., \& Oosthuizen, L. C. (2015). Challenges influencing teachers' involvement in continuous professional development: A South African perspective. Teaching and Teacher Education, 51, 203-212.

Gobena, G. A. (2018). Factors Affecting In-Service Teachers' Motivation: Its Implication to Quality of Education. International Journal of Instruction, 11(3), 163178. https://doi.org/10.12973/iji.2018.11312a

Gu, S. L. (2014). The Relationships Between Instructional Leadership Behavior, School Climate and Teacher Efficacy in Secondry Schools in Kedah. Thesis Doctor of Philosophy, Northern University of Malaysia.

Hallinger, P. (2010). Making education reform happen: Is there an 'Asian' way? School Leadership and Management, 30(5), 401-419.

Handoko, T. H. (2001). Personnel management and human resources. (In Indonesia:Manajemen Personalia Dan Sumber Daya Manusia. Yogyakarta: BPFE)

Hein, V. (2012). The Effect of Teacher Behavior on Students Motivation and Learning Outcomes: A Review.ActaKinsiologiaeUniversitatis, 18, 9-19.

Hendriks, M., \& Steen, R. (2012). Results from school leadership effectiveness studies (2005-2010). In J. Scheerens (Ed.), School leadership effects revisited: Review and meta-analysis of empirical studies (pp. 65-129). New York: Springer.

Herdian D. A. (2010). Compensation influence on the performance of employees of pt .Slamet lasting purbalingga with the motivation work as variable intervening. Thesis. (In Indonesia: Pengaruh Kompensasi terhadap Kinerja Karyawan PT. Slamet Langgeng Purbalingga dengan Motivasi Kerja sebagai Variabel Intervening. Hasil tesis) 
Hoy, W. K., \& Tarter, C. J. (2011). Positive psychology and educational administration: An optimistic research agenda. Educational Administration Quarterly, 47(3), 427-445.

Huber, S. G., \& Muijs, D. (2010). School leadership effectiveness: The growing insight in the importance of school leadership for the quality and development of schools and their pupils. In S. G. Huber (Ed.), School leadership-International perspectives (pp. 5777). New York: Springer.

Ismail, S. N., Don, Y., Husin, F., \& Khalid R. (2018). Instructional Leadership and Teachers' Functional Competency across the 21st Century Learning. International Journal of Instruction, 11(3), 135-152. https://doi.org/10.12973/iji.2018.11310a

Kakar, S., \& Pathan, Z. (2017). Exploring the Motivational Strategies Practiced by Pakistani EFL Teachers to Motivate Students in Learning English Language. International Journal of English Linguistics; Vol. 7, No. 2; 2017 ISSN 1923-869X EISSN 1923-8703 Published by Canadian Center of Science and Education.

Kempa. R. (2015). Leadership principal (In Indonesia: Kepemimpinan Kepala Sekolah. Yogyakarta: Ombak.

Klassen, R. M., \& Chiu, M. M. (2010). Effects on teachers' self-efficacy and job satisfaction: Teacher gender, years of experience, and job stress. Journal of Educational Psychology, 102(3), 741-756.

Li, C., \& Zhou, T. (2017). An Exploratory Study on the Relationship between Demotivation and Academic Fields among Chinese EFL Learners.Arab World English Journal (AWEJ), 8(1). DOI: https://dx.doi.org/10.24093/awej/vol8no1.4

MashhadiHeidar, D., Pahlavan, M., \& Kavian, M. (2017). Sociological Study of Motivation and its Effect on Iranian Teachers' Learning English. Journal of Social Studies of Youth. ISSN: 2476-5198, SSYJ 2017, 7(24), 49-60.

Melekoglu, M. A., \& Wilkerson, K. L. (2013). Motivation to read: How does it change for struggling readers with and without disabilities? International Journal of Instruction, 6(1), 77-88.

Molavi, A., Biria, R., \& Chalak, A. (2018). Effect of Teacher Motivational Practices and Student Demotivation on Request and Refusal Speech Acts Produced by Iranian EFL Learners. International Journal of Instruction, 11(3), 347-362. https://doi.org/10.12973/iji.2018.11324a

Moolenaar, N. M., Sleegers, P. J. C., \& Daly, A. J. (2012). Teaming up: Linking collaboration networks, collective efficacy, and student achievement. Teaching and Teacher Education, 28(2), 251-262.

Notanubun, Z. (2015). Leadership in education institutions (In Indonesia: Kepemimpinan Pada Institusi Pendidikan. Yogyakarta: Rangkang Education) 
Ofojebe, W. N. (2010). Teachers' motivation and its influence on quality assurance in the Nigerian educational system. African Research Review, 4(2). doi:10.4314/afrrev.v4i2.58352

OKO, O. (2014). Impact of Teacher Motivation on Academic Performance of Students. National Association of Mathematics Students' Conference/Seminar held at the College Auditorium, NwaforOrizu College of Education, Nsugbe, Anambra State, Nigeria Date: 19th-23rd November 2014

Papi, M., \& Abdollahzadeh, E. (2012). Teacher motivational practice, student motivation, and possible L2 selves: An examination in the Iranian EFL context. Language Learning, 62(2), 571-594.

Rahabav, P. (2014). Leadership principal in the otonomisasi (In Indonesia: Kepemimpinan Kepala Sekolah Di Era Otonomisasi. Yogyakarta: PT Kanisius).

Rastegari, S., \& Narafshan, M. (2017). Fostering EFL Learners' Motivation: Quick and Narrow Listening Strategies. Journal of Advances in English Language Teaching, 5(2), $13-24$.

Riana, I. G. (1996). The influence of leadership and compensation for satisfaction of work and employee performance (In Indonesia: engaruh kepemimpinan dan kompensasi terhadap Kepuasan kerja dan kinerja karyawan (studi pada pt. Bpr sri artha lestari denpasar" Fakultas Ekonomi dan Bisnis Universitas Udayana (UNUD), Bali, Indonesia. Hasil Tesis)

Rosnarizah, A. H. (2015). Distributed leadership, contextual factor and teacher selfeficacy in Malaysia. Educational Leadership Journal, 2(4).

Siagian, P. S. (2004). The theory of motivation and it can be applied (In Indonesia: Teori Motivasi Dan aplikasinya. Jakarta: PT Rineka Cipta)

Sugiyono. (2014). Statistics for research (In Indonesai: Statistik Untuk Penelitian. Bandung: Alfabeta)

Supardi. (2014). Teacher performance (In Indonesia:Kinerja Guru. Jakarta: PT Raja Grafindo Persada).

Sutherland, L., Howard, S., \& Markauskaite, L. (2010). Professional identity creation: Examining the development of beginning preservice teachers' understanding of their work as teachers. Teaching and Teacher Education, 26(3), 455-465.

Trent, J. (2010). Teacher education as identity construction: Insights from action research. Journal of Education for Teaching, 36(2), 153-168.

Act of republic of Indonesia No 14 of 2005 on teachers and lecturers (In Indonesia: Undang-undang Republik Indonesia No 14 Tahun 2005 tentang Guru dan Dosen)

Wu, J., \& Lee, M. (2017). The relationships between test performance and students' perceptions of learning motivation, test value, and test anxiety in the context of the 
English benchmark requirement for graduation in Taiwan's universities. Language Testing in Asia (2017) 7:9 DOI 10.1186/s40468-017-0041-4 